Retraction

\title{
Retracted: N-(1-Pyrenyl) Maleimide Induces Bak Oligomerization and Mitochondrial Dysfunction in Jurkat Cells
}

\author{
BioMed Research International \\ Received 2 September 2021; Accepted 2 September 2021; Published 28 October 2021 \\ Copyright (c) 2021 BioMed Research International. This is an open access article distributed under the Creative Commons \\ Attribution License, which permits unrestricted use, distribution, and reproduction in any medium, provided the original work \\ is properly cited.
}

BioMed Research International has retracted the article titled "N-(1-Pyrenyl) Maleimide Induces Bak Oligomerization and Mitochondrial Dysfunction in Jurkat Cells" [1] due to concerns regarding the reliability of the results. The journal has been made aware [2] that the article includes nucleotide sequences which appear to be incorrectly targeted, as follows:

- CTTCGTACCATTTTTG targets ZHX3 mRNA, not Bak as described in the article

- TGTGTGAAAGTTTTTG targets YWHAEP7 noncoding RNA, not Bid as described in the article

- TTGGCAACCGCTTTTTG targets Luciferase 1 in P. pyralis, but only with $93 \%$ identity

The authors did not respond to our requests for clarification, and due to the above concerns, it is being retracted with the agreement of the journal and the editorial board.

\section{References}

[1] P.-R. Huang, S.-C. Hung, C.-C. Pao, and T.-C. V. Wang, "N(1-Pyrenyl) Maleimide Induces Bak Oligomerization and Mitochondrial Dysfunction in Jurkat Cells," BioMed Research International, vol. 2015, Article ID 798489, 10 pages, 2015.

[2] C. Labbé, N. Grima, T. Gautier, B. Favier, and J. A. Byrne, "Semi-automated fact-checking of nucleotide sequence reagents in biomedical research publications: the Seek \& Blastn tool," PLoS One, vol. 14, no. 3, 2019. 